\title{
Ekonomi Politik Investasi Perusahaan Multinasional di Era Pemerintahan Joko Widodo
}

\section{Farhan Alam}

Universitas Gadjah Mada

\section{Abstrak:}

Artikel ini membahas upaya negara untuk menghindari ketergantungan dalam hubungan antara negara berkembang dan perusahaan multinasional (PMN). Kelompok Neo-Marxis, khususnya teori ketergantungan menganggap bahwa PMN adalah bagian dari kepentingan negara kapitalis pusat di negara berkembang. Oleh karena itu, keberadaan PMN cenderung membuat negara berkembang bergantung padanya. Hal ini berbeda dengan kasus pengelolaan investasi PMN di Indonesia. Pada pemerintahan Joko Widodo, terlihat bahwa negara berkembang bisa memiliki daya tawar yang cukup kuat sehingga dapat melakukan negosiasi dengan PMN. Dengan menggunakan studi pustaka, artikel ini mengumpulkan berbagai data sekunder terkait argumen pemerintah terhadap fenomena PMN melalui media massa dan dokumen pemerintah. Indonesia melalui stabilitas ekonomi dan politik berupaya untuk meningkatkan posisi tawar sehingga akan terjadi kompetisi yang adil diantara PMN ketika berinvestasi. Hasil dari peningkatan daya tawar ini adalah hubungan yang lebih seimbang antara negara dengan PMN. Keseimbangan hubungan menjadikan kepentingan negara berkembang dan PMN dapat saling beriringan tanpa adanya pihak yang mendominasi. Ini menunjukkan pada kita bahwa ketergantungan dapat dihindari apabila pemerintah memiliki kemampuan untuk meningkatkan posisi tawar negara berkembang.

\section{Keywords:}

investasi; ketergantungan; negara berkembang; perusahaan multinasional

\section{Pendahuluan}

$\mathrm{P}$ erubahan besar yang terjadi sebagai bagian dari globalisasi adalah perkembangan Perusahaan Multinasional (PMN) yang mulai melebarkan sayap bisnisnya ke segala penjuru dunia. Globalisasi adalah salah satu faktor yang menjadikan peran PMN menjadi lebih dominan (Madeley, 2009). Meskipun sejatinya PMN adalah entitas ekonomi, dominannya pengaruh PMN terhadap negara menjadikan PMN masuk ke dalam diskusi politik.

Indonesia adalah salah satu negara berkembang yang sudah tidak asing lagi dengan investasi PMN. Mulai dari era Orde Lama hingga pasca reformasi, Indonesia 
masih membuka pintu bagi investasi PMN. Pusat bisnis dan kawasan industri pun bermunculan sebagai efek domino dari kegiatan perusahaan multinasional.

Kemunculan industri Indonesia tidak lepas dari peranan PMN. Kemampuan modal dan teknologi yang dibawa oleh PMN membantu untuk memunculkan perkembangan industri dasar serta menggeser orientasi pembangunan daerah yang agraris menjadi orientasi industri (Anoraga, 1995). Melalui Penanaman Modal Asing (PMA), PMN di Indonesia berupaya untuk berbisnis di berbagai sektor. Berdasarkan laporan Realisasi Penanaman Modal PMDN-PMA Triwulan IV dan Januari-Desember Tahun 2017 yang dikeluarkan oleh Badan Koordinasi Penanaman Modal (BKPM) RI (2018), sektor dengan investasi PMA tertinggi adalah sektor pertambangan dengan investasi sebesar US\$4.375,9 juta dengan jumlah proyek sebanyak 729 sepanjang periode Januari-Desember 2017. Singapura menjadi negara asal PMA terbanyak di Indonesia pada periode Januari-Desember 2017 dengan total investasi sebesar US\$ 8.441,6 Juta melalui 5.951 proyek.

Diskusi politik tentang PMN lazimnya Udofia (1984) membahas dampak ekonomi politik PMN di negara dunia ketiga PMN dan eksploitasi sumber daya alam, menurut Mohan, Asante, \& Abdulai (2018) PMN dan pembangunan dunia kontemporer (May, 2017). Dari bahasan yang dilakukan ilmuwan politik, perdebatan yang sering muncul adalah hubungan yang terkadang konfliktual antara negara dengan PMN. Hubungan yang konfliktual itu sendiri diyakini kaum Neo-Marx sebagai konsekuensi dari hubungan yang tidak imbang antara kekuatan negara kapitalis dengan pemerintah negara berkembang. Kecurigaan kaum Neo-Marx dengan menggunakan teori ketergantungan melihat bahwa keberadaan PMN di negara berkembang adalah bentuk ketergantungan negara berkembang terhadap negara maju. Hal tersebut perlu dilihat lebih lanjut, apakah ketergantungan tersebut adalah dampak yang tidak dapat dihindari, atau ternyata ada cara yang dapat dilakukan pemerintah negara berkembang untuk mengubah dependensi menjadi interdependensi. Apakah ketergantungan adalah keniscayaan atau sebuah dampak dari kegagalan pemerintah negara berkembang dalam meningkatkan posisinya terhadap PMN.

Kehadiran PMN di negara berkembang sendiri menjadi perdebatan antara kubu yang optimis dan pesimis. Kubu optimis yang diwakili Neo-Liberal meyakini PMN dapat menjadi dorongan bagi kekuatan ekonomi negara berkembang. Sedangkan kubu pesimis yang diwakili Neo-Marx sering kali menganggap PMN sebagai kehadiran kekuatan asing di dalam negeri dan upaya negara maju untuk melakukan penghisapan kepada negara berkembang. Sebaliknya, kubu optimis yakin akan dampak positif PMN tetapi tidak mempertimbangkan dampak ketergantungan terhadap PMN. Perdebatan ini menunjukkan bagi kedua kubu bahwa seolah-olah hubungan antara negara dengan PMN adalah tarik ulur hubungan antara siapa membutuhkan siapa. 
Perdebatan dua kubu ini terus berlanjut meskipun sejatinya antara negara dengan PMN dapat tumbuh pola interdependensi. Seperti yang terjadi di Indonesia pada masa Orde Baru dimana daya tawar pemerintah Indonesia meningkat sejalan dengan kondisi ekonomi dan politik yang stabil pada masa itu sehingga antara negara berkembang dengan PMN bisa saling membutuhkan (Nizamuddin, 2008). Di satu sisi, negara membutuhkan modal PMN, di sisi lain PMN membutuhkan negara sebagai akses masuk mereka untuk melakukan ekspansi bisnis (Babic, Fichtner, \& Heemskerk, 2017; Mohan et al., 2018). Optimisme yang mampu menciptakan interdependensi memang jarang terjadi, terutama interdependensi yang seimbang. Pada umumnya, negara berkembang tetap jatuh dalam bayang kekuatan negara maju dan kembali terjebak pada ketergantungan.

Melihat kehadiran PMN yang telah berbisnis di Indonesia dari masa presiden Indonesia pertama, cukup menjadi pertanyaan untuk penganut teori ketergantungan: Apakah sepanjang waktu itu kepentingan Indonesia tidak bisa mengalahkan kepentingan negara kapitalis pusat. Kemudian di era pemerintahan Jokowi yang mulai menjabat sebagai presiden ke-7 Indonesia pada Tahun 2014, terlihat adanya upaya peningkatan posisi tawar negara terhadap PMN. Kebijakan mendukung peningkatan investasi PMN oleh pemerintahan Jokowi tidak lantas membuat negara jatuh ke dalam ketergantungan investasi asing, sebaliknya PMN pun secara tidak langsung menjadi tergantung pada Indonesia.

Penulis meyakini bahwa pemerintah Indonesia di era Jokowi menggunakan perspektif optimis terhadap PMN namun tidak berarti pemerintah menginginkan terciptanya ketergantungan negara terhadap PMN. Justru pola yang akan diciptakan adalah saling ketergantungan antara negara dengan PMN yang sangat menguntungkan bagi kedua belah pihak. Saling ketergantungan dapat diperoleh pemerintah negara berkembang dengan meningkatkan posisi tawar mereka terhadap PMN melalui stabilisasi ekonomi dan politik. Artikel ini melihat bahwa peningkatan daya tawar pemerintah negara berkembang melalui stabilitas ekonomi dan politik sebagai kekuatan yang dimiliki pemerintah negara berkembang untuk menandingi kekuatan PMN. Maka dari itu, artikel ini akan melihat pola interdependensi dengan berfokus pada upaya pemerintah pada masa kepemimpinan Jokowi dalam menarik investasi PMN menggunakan stabilitas ekonomi dan politik.

Perspektif interdependensi akan digunakan sebagai dasar teoritik dalam melihat dukungan pemerintahan Jokowi terhadap investasi PMN. Argumen yang mendasari artikel ini yakni (1) PMN dipandang oleh pemerintahan Jokowi berperan bagi ekonomi Indonesia, (2) Upaya yang dilakukan pemerintahan Jokowi merupakan upaya pembentukan interdependensi antara negara dan PMN, (3) Negara berkembang dapat menegosiasikan daya tawar mereka terhadap PMN (Nizamuddin, 2008). Berdasarkan tiga argumen tersebut, artikel ini akan membahas penggunaan perspektif optimis 
terhadap PMN di Indonesia dan pembentukan pola interdependensi yang dilakukan pada era pemerintahan Jokowi.

\section{Optimis vs Pesimis: Perspektif terhadap PMN}

PMN merupakan perusahaan yang beroperasi di lebih dari satu negara. Jika dalam kasus Indonesia, maka PMN beroperasi di Indonesia dibawah regulasi penanaman modal asing. PMN memiliki ciri yaitu terdiri dari perusahaan induk dan anak perusahaan, berada di lebih dari satu negara dimana PMN melakukan kegiatan ekonomi dasar seperti produksi dan perdagangan (Sklar, 1976).

Dalam pengelolaan sumber daya, negara dilihat sebagai regulator dan pemberi akses bagi PMN untuk dapat berinvestasi di dalam negeri (Babic et al., 2017; Mohan et al., 2018). Hal tersebut juga berlaku untuk semua sektor investasi, tidak hanya investasi PMN berbasis sumber daya. Sehingga perdebatan boleh-tidaknya dan bagaimana PMN berinvestasi akan berada pada level negara. Perdebatan antara kubu optimis dengan kubu pesimis berada pada tatanan dampak dan makna dari keberadaan PMN di negara berkembang. Perdebatan itu mengerucut dalam dua kutub berseberangan, yakni Kubu Neo-Marx dan Neo-liberal.

Neo-Marx pesimis terhadap PMN dengan beranggapan bahwa kehadiran investasi PMN di negara berkembang merupakan wujud dari ketergantungan negara berkembang terhadap kekuatan modal asing. Teori ketergantungan itu sendiri menjelaskan bahwa kehadiran PMN di negara berkembang memiliki sisi politis. PMN adalah bagian dari negara kapitalis pusat untuk melakukan eksploitasi ekonomi negara dunia ketiga (Leonard, 1979).

Dari sisi negara, terkadang para pengambil keputusan memiliki latar belakang atau bahkan masih merupakan seorang pengusaha. Pertemuan antara kehadiran politisipengusaha dengan kepentingan ekspansi bisnis PMN semakin menguatkan peluang bisnis PMN di negara berkembang. Sementara itu, kubu Neo-Marx mengkritik interdependensi dalam liberalisasi seperti yang digaungkan Neo-liberal sebagai dampak yang tidak mungkin karena justru yang akan tercipta adalah unequal exchange (Umar, 2012).

Interdependensi oleh kubu Neo-liberal dianggap sebagai jalan tengah bagi hubungan antara negara dengan PMN yang memungkinkan semua pihak untuk saling membutuhkan satu sama lain. Hubungan interdependensi dilihat sebagai hubungan PMN yang membutuhkan negara sebagai regulator dalam keamanan dan perlindungan hak, sedangkan negara membutuhkan PMN sebagai sumber dana dan lapangan pekerjaan (Babic et al., 2017). Interdependensi ini sangat membutuhkan kondisi yang setara dimana negara berkembang juga memiliki daya tawarnya yang berbentuk kebijakan dan potensi ekonomi.

Jika kita melihat pada pandangan Neo-Marx tentang adanya unequal exchange, maka kita telah menemukan inti dari permasalahan hubungan antara negara berkembang dengan PMN. Unequal exchange menunjukkan adanya ketidakseimbangan kekuatan yang dimiliki negara berkembang sehingga tidak mampu menandingi kekuatan 
PMN. Pemerintah negara berkembang dapat menggunakan stabilitas ekonomi dan politik untuk meningkatkan posisi tawar terhadap PMN.

Nizamuddin (2008) setidaknya pernah meneliti terkait peningkatan daya tawar pemerintah negara berkembang terhadap PMN di bidang industri manufaktur di tiga negara Asia. Salah satu yang dibahas adalah Indonesia pada masa Orde Baru. Temuannya menunjukkan semakin beresikonya pasar atau kondisi ekonomi-politik sebuah negara berkembang maka posisi tawar negara tersebut akan menurun. Begitupun sebaliknya, posisi tawar pemerintah negara berkembang terhadap PMN akan meningkat jika ekonomi dan politik negara tersebut dapat dikatakan stabil dan berpotensi besar bagi keuntungan jika berinvestasi. Jadi, peningkatan posisi tawar pemerintah negara berkembang terhadap PMN dapat dilakukan melalui stabilitas ekonomi dan politik, termasuk penurunan risiko pasar. Tanpa stabilitas ekonomi dan politik maka pemerintah negara berkembang tidak memiliki kekuatan dalam relasinya dengan PMN. PMN sangat mempertimbangkan faktor ekonomi dan politik sebuah negara yang akan dijadikan target investasi. Dalam hubungan antara pemerintah negara berkembang dengan PMN, maka daya tawar negara berkembang melalui stabilitas ekonomi dan politik adalah kekuatan yang dimiliki pemerintah negara berkembang untuk menandingi kekuatan kapital PMN.

Dalam mengerjakan artikel ini, penulis mengggunakan pendekatan penelitian pustaka dengan teknik pengumpulan data melalui dokumen atau pustaka. Data yang dikumpulkan berupa data sekunder dan argumen-argumen yang digunakan pemerintah dalam periode pemerintahan Jokowi melalui media massa dan dokumen resmi pemerintah dalam menanggapi fenomena PMN. Argumen pemerintah dalam hal ini merupakan pandangan yang dikemukakan oleh Jokowi sebagai presiden, Kementerian yang terkait dengan investasi PMN seperti Kementerian Keuangan, Kementerian Perindustrian dan Badan Koordinasi Penanaman Modal (BKPM) selaku badan yang memiliki otoritas untuk mengatur investasi di Indonesia. Data tersebut akan menunjukkan bagaimana kepentingan pemerintah dan pengelolaan PMN di Indonesia yang dilakukan pada era Jokowi. Fokus sektor industri PMN yang dilihat dalam artikel ini berada pada sektor industri manufaktur.

\section{Dinamika Perusahaan Multinasional di Indonesia}

Sejarah mencatat masuknya PMN di Indonesia dimulai pada era Orde Lama dengan diterbitkannya Undang-undang Nomor 78 Tahun 1958 tentang penanaman modal asing. Penetapan Undang-undang penanaman modal asing menandakan adanya kebutuhan pemerintah Orde Lama terhadap modal untuk meningkatkan kondisi ekonomi Indonesia. Hal ini menunjukkan bahwa investasi PMN dinilai sebagai tambahan modal untuk menutupi kekurangan modal dalam negeri. Sayangnya, PMN tidak merasakan keamanan dalam berinvestasi di Indonesia pada era Orde Lama. Setelah kemerdekaan Indonesia pada Tahun 1945, perusahaan asing yang beroperasi di Indonesia berhadapan pada kondisi politik yang sangat berisiko bagi PMN. Penolakan 
terhadap investasi asing sebagai dampak dari semangat anti-kolonialisme dan konflik perebutan wilayah Irian Barat antara Indonesia dengan Belanda. Penolakan tersebut kemudian mengarahkan pada desakan nasionalisasi PMN, terutama yang dimiliki Belanda (White, 2017).

Orde Baru dibawah kepemimpinan Presiden Soeharto kemudian menggantikan pemerintahan Orde Lama. Pada saat itu, pemerintah Indonesia membuka peluang bagi PMN untuk melakukan bisnis di Indonesia melalui investasi asing dengan diberlakukannya Undang-undang Nomor 1 Tahun 1967 tentang Penanaman Modal Asing. Penetapan Undang-undang tersebut menunjukkan bahwa Presiden Soeharto lebih memilih perspektif optimis dan mendukung investasi PMN. Kepentingan pemerintah berlandaskan pada pertimbangan bahwa sumber daya yang dimiliki Indonesia belum sepenuhnya dapat dimanfaatkan karena kurangnya modal, pengalaman dan teknologi. Pertimbangan tersebut menjadikan regulasi ini syarat akan perspektif Neo-liberal yang menganggap bahwa modal dan teknologi yang dibawa PMN dapat dimanfaatkan untuk kepentingan ekonomi negara berkembang. Kepentingan lainnya yang terlihat di dalam undang-undang ini yakni pemerintah Orde Baru menginginkan adanya percepatan pembangunan ekonomi sehingga berpandangan dengan masuknya investasi PMN dapat mempercepat pertumbuhan ekonomi Indonesia. Istilah perusahaan modal asing digunakan untuk menyebut perusahaan multinasional.

Pemerintah Orde Baru menggunakan strategi insentif pajak untuk mengundang investasi PMN. Pemerintah juga memberikan jaminan untuk tidak akan melakukan nasionalisasi kepada PMN yang berinvestasi di Indonesia. Jika memang mendesak untuk dilakukan nasionalisasi maka akan diberikan kompensasi kepada PMN yang memiliki investasi tersebut. Jaminan bahwa negara tidak akan melakukan nasionalisasi terhadap PMN merupakan kabar baik bagi PMN untuk berinvestasi di Indonesia karena pada periode pemerintahan sebelumnya, Orde Lama, cenderung melakukan upaya nasionalisasi bagi aset asing. Namun, pemerintahan Orde Baru tetap memiliki sisi yang dinilai negatif bagi PMN yakni prosedur birokrasi yang rumit dan korupsi (White, 2017).

Strategi-strategi yang dilakukan pemerintah Orde Baru terhadap PMN meningkatkan posisi tawar Indonesia di kalangan PMN. Nizamuddin (2008) melihat fenomena tersebut terjadi karena semakin menariknya pasar atau kegiatan ekonomi di sebuah negara maka akan mengurangi tingkat ketergantungan negara terhadap PMN. Bahkan, justru PMN yang bergantung terhadap perekonomian negara sasaran investasinya. Strategi yang dilakukan pemerintahan Soeharto dapat dikatakan memberikan arena dan kemudahan bagi PMN untuk bersaing satu sama lain memperebutkan sumber daya dan perekonomian Indonesia sehingga menjadikan Indonesia bernilai tinggi di mata PMN. Arena investasi yang dibuka lebar dan kemudahan yang diberikan, ditambah pula dengan iklim ekonomi dan politik yang ditekan oleh Soeharto agar tetap stabil semakin meningkatkan posisi tawar Indonesia, sedangkan PMN semakin ketergantungan terhadap Indonesia. 
Pada Tahun 1970, pemerintahan Orde Baru melakukan perubahan terhadap Undang-undang Nomor 1 Tahun 1967 tentang penanaman modal asing menjadi Undang-undang Nomor 11 Tahun 1970 tentang perubahan dan tambahan Undangundang No. 1 Tahun 1967. Adapun perubahan tersebut meliputi pasal 15, pasal 16, pasal 17 yang memuat tentang ketentuan kelonggaran pajak bagi PMN yang melakukan investasi. Pemerintah berupaya untuk menarik lebih banyak investasi PMN dengan ditetapkannya perubahan terhadap regulasi penanaman modal asing melalui strategi insentif investasi dan kelonggaran pajak bagi PMN yang akan berinvestasi di Indonesia.

Dinamika PMN pasca reformasi terjadi pergeseran paradigma yang semula berfokus pada industri berbasis sumber daya alam menjadi berbasis industri konsumsi. PMN berupaya mendapatkan potensi konsumen Indonesia dengan membuka operasional produksi mereka di Indonesia. Pada 2013, The Boston Consulting Group dalam tulisan Cochrane (2013) memperkirakan masyarakat kelas menengah dan konsumer yang tergolong makmur di Indonesia akan meningkat dua kali lipat mencapai 141 juta pada Tahun 2020. Perkiraan jumlah konsumen tersebut jelas menjadi gambaran yang menguntungkan bagi PMN untuk melakukan produksi di Indonesia. Jumlah konsumen yang tinggi merupakan peluang besar bagi PMN di bidang produksi barang konsumsi. Namun, Indonesia pada Tahun 2013 masih memiliki kendala yang menghambat laju investasi PMN diantaranya 80 hari untuk mendapatkan izin usaha dan korupsi. Pada Tahun tersebut, posisi Indonesia turun sebanyak 13 peringkat dari Tahun 2010 dalam survey negara dengan kemudahan berbisnis menurut Bank Dunia dan Indonesia memiliki indeks persepsi korupsi di urutan 118 dari 176 negara menurut Transparency International (Cochrane, 2013).

UU 25 Tahun 2007 tentang penanaman modal menjadi landasan bagi penanaman modal PMN di Indonesia yang masih berlaku di era pemerintahan Jokowi. Sebelum diberlakukannya undang-undang ini, pembahasan antara modal asing dan modal dalam negeri dipisahkan kedalam dua regulasi yakni UU Nomor 1 Tahun 1967 tentang Penanaman Modal Asing dan UU Nomor 6 Tahun 1968 tentang Penanaman Modal Dalam Negeri. Pembahasan kedua jenis penanaman modal tersebut kemudian digabungkan kedalam satu regulasi Undang-undang.

Otonomi daerah merupakan salah satu hal baru yang dimasukkan ke dalam regulasi penanaman modal. Jika pada UU Nomor 1 Tahun 1967 terasa sentralistik, maka UU Nomor 25 Tahun 2007 mulai membawa keterlibatan daerah dalam mengelola penanaman modal melalui otonomi daerah. Pandangan optimis dapat kita temukan di bagian pertimbangan Undang-undang Nomor 25 Tahun 2007 tentang Penanaman Modal yang mengatakan bahwa peningkatan penanaman modal, baik itu modal dalam negeri atau luar negeri perlu ditingkatkan guna mengolah potensi ekonomi menjadi kekuatan ekonomi riil. 


\section{Pandangan Pemerintah terhadap PMN}

UU Nomor 25 Tahun 2007 tentang penanaman modal mengatur PMN sebagai badan usaha asing dapat melakukan penanaman modal asing baik dengan menggunakan modal asing seluruhnya maupun dengan menjalin kerjasama dengan penanam modal dalam negeri. Regulasi tersebut menjadi tanda PMN memiliki kesempatan berinvestasi di Indonesia.

Pemerintahan Jokowi tidak melakukan perubahan terhadap UU tersebut sehingga tetap menjadi landasan bagi kehadiran PMN di Indonesia. Selain memberikan kesempatan bagi PMN untuk berinvestasi di Indonesia, pemerintahan Jokowi juga beberapa kali mengisyaratkan upaya menarik investasi PMN ke Indonesia.

Sesaat setelah memenangkan pemilihan presiden 2014, Jokowi diwawancarai oleh Jonathan Tepperman, editor manajer Foreign Affairs. Wawancara yang berlangsung pada pertengahan September 2014 tersebut membahas mulai dari pengalaman yang dihadapi Jokowi dalam pilpres 2014 hingga langkah-langkah yang akan ditempuh Jokowi sebagai presiden kedepannya. Salah satu poin yang juga disinggung dalam wawancara ini yakni pandangan Jokowi terhadap pengembangan sektor investasi. Jokowi mengatakan bahwa Indonesia terbuka bagi investasi PMN, terutama di bidang pembangunan infrastruktur, industri, dan manufaktur (Widodo, 2014). Terbukanya Indonesia bagi investasi dipandang oleh Jokowi dapat membangun infrastruktur dan ekonomi Indonesia yang sangat penting karena pada akhirnya berdampak pada terciptanya lapangan kerja dan kehidupan masyarakat yang lebih baik. Pandangan tersebut menunjukkan bahwa pemerintah Indonesia di era Jokowi memiliki optimisme terhadap investasi PMN.

Jokowi mengundang investasi asing ke Indonesia dalam beberapa pertemuan resmi. Salah satunya yakni ketika berada di KTT ASEAN-Amerika Serikat pada 17 Februari 2016. Pada kesempatan tersebut, Jokowi mengundang perusahaan-perusahaan multinasional untuk melakukan investasi. Undangan tersebut dipertegas dengan pernyataan Jokowi bahwa pemerintah Indonesia telah mempermudah perizinan PMN untuk berinvestasi di Indonesia. Jokowi juga menyampaikan tentang stabilnya pertumbuhan ekonomi Indonesia disaat pasar modal Cina dan Amerika Serikat menurun sebagai akibat dari harga minyak dunia yang anjlok (Martini, 2015). Iklim ekonomi yang stabil dan kebijakan yang mempermudah aktivitas PMN merupakan daya tarik tersendiri dari suatu negara dalam pandangan PMN. Kedua hal tersebut menjadi pertimbangan penting bagi PMN dalam memilih negara yang akan mereka tanamkan investasi. PMN menganggap pertimbangan tersebut dapat menjamin keuntungan dan keberlangsungan kegiatan ekonomi mereka ketika sudah menanamkan modal di negara berkembang. Dengan menyadari bahwa PMN sangat tertarik dengan keberadaan faktor tersebut, maka menjadi wajar jika pemerintah negara berkembang seperti Indonesia menggunakan strategi-strategi yang berkaitan dengan pelonggaran regulasi investasi asing dan 
perbaikan iklim ekonomi dalam negeri untuk menarik investasi asing masuk ke negaranya.

Kejadian hampir serupa dengan kondisi ekonomi tahun 2016 terjadi pada tahun 2011 ketika ekonomi di kawasan Eropa, Amerika Serikat dan Amerika Selatan sedang dilanda krisis. Disaat yang bersamaan dengan krisis tersebut, negara-negara di wilayah Asia Tenggara sedang mengupayakan kawasan perdagangan bebas dalam kerjasama regional ASEAN. Kawasan Asia Tenggara kemudian menjadi target bagi investasi PMN yang mulai mencari daerah baru di luar kawasan yang sedang dilanda krisis ekonomi. Indonesia pun menjadi salah satu negara di kawasan Asia Tenggara yang dilihat oleh PMN pada waktu itu sebagai negara sasaran investasi yang potensial. Menurut Chieff Economist untuk Economic Research Institute for ASEAN and East Asia (ERIA), Fukunari Kimura, Indonesia memiliki banyak keunggulan komparatif, terutama dalam sektor sumber daya alam serta melimpahnya sumber daya manusia. Selain itu, terdapat kesempatan bagi Indonesia untuk menarik lebih banyak investasi PMN dengan mempertimbangkan keunggulan iklim ekonomi Indonesia berupa pertumbuhan Produk Domestik Bruto (PDB) pada saat itu yang diperkirakan mencapai angka 6,4 persen, angka tertinggi dibandingkan dengan negara lain di kawasan ASEAN (Budi, 2011).

Jika kita melihat kondisi ekonomi tahun 2011 yang kemudian terulang kembali di tahun 2016, maka dapat kita temukan pola yang serupa diantara dua era kepemimpinan, SBY dan Jokowi dalam mengelola investasi PMN. Pola tersebut adalah kecenderungan untuk memanfaatkan kondisi pertumbuhan ekonomi untuk mengundang investasi PMN. Data terkait ekonomi Indonesia menjadi rujukan bagi PMN untuk berinvestasi sehingga Jokowi menggunakannya untuk menarik investasi PMN. Strategi ini menunjukkan pemerintah berupaya membentuk kekuatan melalui stabilitas pertumbuhan ekonomi Indonesia untuk meningkatkan posisi tawarnya terhadap PMN.

Pemerintah Indonesia juga memanfaatkan data yang mendukung Indonesia sebagai negara ramah investasi. Seperti yang terjadi pada tahun 2017, ketika hasil survey United Nations Conference on Trade and Development (UNCTAD) menunjukkan bahwa Indonesia menempati peringkat keempat sebagai negara tujuan investasi yang prospektif pada kurun waktu 2017-2019. Posisi Indonesia yang berada pada peringkat keempat di tahun 2017 menunjukkan kenaikan dari Tahun sebelumnya ketika Indonesia menempati peringkat ke delapan. Indonesia menjadi negara anggota ASEAN dengan peringkat tertinggi pada hasil survey tersebut. Peringkat pertama yakni Amerika Serikat, disusul Cina dan India. Presiden Jokowi pun menanggapi hasil survey tersebut sebagai prestasi bagi Indonesia karena telah mendapatkan kepercayaan dunia internasional. Jokowi beranggapan bahwa hasil survey layak investasi tersebut dapat bermanfaat bagi masuknya arus modal dan investasi ke daerah yang dapat meningkatkan lapangan kerja baru dan peningkatan kesejahteraan (Tempo.co, 2017). Dengan menggunakan hasil survey tersebut, pemerintah dapat menarik lebih banyak investasi masuk ke Indonesia 
karena status ramah investasi akan memberikan stigma yang positif bagi Indonesia di mata PMN. Selain itu, argument Jokowi tentang dampak positif dari hasil survey layak investasi terhadap perekonomian daerah dapat dilihat sebagai respon dari penganut perspektif yang meragukan pengaruh positif investasi PMN. Jokowi berupaya meyakinkan publik bahwa investasi PMN dapat mengurangi kemiskinan dengan menyediakan lapangan kerja baru dan menambah peredaran uang di daerah.

Selain menarik investasi PMN dengan memanfaatkan kondisi ekonomi, pemerintahan Indonesia di era Jokowi juga menggunakan ranah kebijakan sebagai strategi. Jokowi dalam wawancaranya dengan editor manajer Foreign Affair, Jonathan Tepperman pada tahun 2014 silam sempat menyinggung kendala yang menghambat PMN untuk berinvestasi di Indonesia adalah masalah perizinan usaha dan lahan sehingga diperlukan adanya inovasi kebijakan yang mempercepat dan mempermudah proses pengajuan izin bagi usaha PMN (Widodo, 2014). Pemilihan kebijakan yang mendukung keberadaan investasi PMN sejalan dengan pernyataan Direktur Senior Perdagangan dan Praktik Daya Saing Global Grup Bank Dunia, Anabel Gonzalez bahwa berdasarkan hasil survey terhadap 750 eksekutif perusahaan multinasional dalam Laporan Daya Saing Investasi Global 2017-2018 terdapat faktor kunci seperti regulasi yang ramah terhadap bisnis, stabilitas politik, keamanan dan kondisi makro ekonomi yang menjadi pertimbangan bagi PMN untuk berinvestasi di negara-negara berkembang (Prayogo, 2017). Dengan merujuk pada hasil survey tersebut, maka dapat menjadi penjelasan mengapa Presiden Jokowi mengupayakan hadirnya kebijakan yang ramah terhadap investasi. Upaya mewujudkan kebijakan yang ramah investasi dapat terlihat pada pernyataan Jokowi ketika berada di KTT ASEAN-Amerika 2016 bahwa pemerintah telah mempermudah perizinan bagi investasi. Selain itu, Jokowi juga mengatakan bahwa Indonesia sedang melakukan reformasi dan mengupayakan untuk membebaskan bisnis dan industri dari undang-undang dan peraturan yang berlebihan (Rina, 2016).

Penggunaan regulasi yang ramah investasi dan bisnis disambut positif oleh pihak PMN. Chevron sebagai salah satu perusahaan multinasional di Indonesia yang bergerak di bidang migas mengapresiasi upaya pemerintah dalam menghadirkan regulasi yang ramah investasi dan bisnis. Chuck Taylor selaku Managing Director Chevron IndoAsia Business Unit mengatakan bahwa penyederhanaan regulasi di bidang usaha berpotensi meningkatkan peluang investasi di Indonesia. Lanjutnya, peningkatan peluang investasi di Indonesia nantinya hadir bersamaan dengan peningkatan lapangan kerja dan pendapatan bagi pemerintah. Regulasi yang dibutuhkan investor seperti Chevron adalah regulasi yang dapat menjamin kepastian dan daya saing fiskal (Putri, Budiati, 2018).

Dengan mempromosikan upaya reformasi kebijakan ramah investasi, pemerintah Indonesia di era Jokowi mengharapkan PMN akan semakin tertarik untuk berinvestasi di Indonesia. Upaya ini tidak jauh berbeda dengan apa yang sudah dibahas ketika pemerintahan Orde Baru membuka pintu bagi investasi PMN. Terdapat upaya 
untuk meningkatkan posisi tawar Indonesia terhadap PMN dan menjadikan PMN bergantung pada Indonesia. Dengan menjadikan negara Indonesia semakin menarik bagi investasi, maka pemerintah mengupayakan posisi tawar yang lebih tinggi dari PMN, kemudian menjadikan PMN bergantung kepada negara berkembang. Hal tersebut merupakan langkah yang dapat kita lihat pada pemerintahan Jokowi, mengupayakan perbaikan stabilitas ekonomi dan politik, kemudian membanggakan membaiknya situasi ekonomi politik untuk menawarkan peluang investasi kepada PMN.

Meskipun pemerintahan Jokowi sudah menggulirkan wacana deregulasi, perusahaan multinasional tetap memiliki keluhan terhadap regulasi yang berlaku di Indonesia. Tercatat sebanyak 40 perwakilan perusahaan multinasional asal Amerika Serikat bersama dengan Dewan Bisnis Amerika Serikat-ASEAN (US-ASEAN Business Council) mengajukan keluhan mereka kepada pemerintah Indonesia. Keluhan tersebut disampaikan di dalam sebuah pertemuan rutin antara Dewan Bisnis Amerika SerikatASEAN dengan pemerintah Indonesia, diantaranya Kementerian Perdagangan dan Kementerian Perindustrian. Seperti di kutip dari laman Tempo.co (2017), pada Juli 2017, Menteri Perindustrian, Airlangga Hartanto memaparkan setidaknya terdapat empat keluhan yang diajukan oleh pihak PMN.

Jika kita melihat secara garis besar, empat keluhan yang diajukan PMN asal Amerika Serikat kepada pemerintah Indonesia setidaknya menunjukkan bahwa masih terdapat dua kekurangan Indonesia di mata PMN. Ketersediaan bahan baku lokal dan implementasi regulasi merupakan fokus dari empat keluhan PMN. Produksi bahan baku lokal masih menjadi kendala bagi PMN, dikarenakan kualitas bahan baku lokal yang belum memenuhi standar minimal kebutuhan PMN atau jumlah produksinya yang masih terbatas. Seperti yang terjadi dalam produksi garam lokal pada periode 2007-2012 yang menunjukkan bahwa Indonesia dinilai belum mampu memproduksi garam untuk kebutuhan industri sehingga kebutuhan garam industri dipenuhi melalui impor garam dari Australia (Baihaki, 2013). Jika produk lokal tidak ditingkatkan secara kualitas dan kuantitas, maka PMN mau tidak mau harus menggunakan bahan baku impor yang pada akhirnya dapat menyingkirkan produk lokal.

Implementasi regulasi adalah fokus berikutnya yang terlihat dalam persoalan skema lelang, pengawasan dan sertifikasi halal. Persoalan implementasi ini menunjukkan kepentingan PMN untuk dapat memenuhi kebutuhan industrinya secara lancar tanpa hambatan regulasi. PMN menganggap bahwa hambatan regulasi dapat mengganggu berjalannya produksi mereka.

Selain membenahi regulasi dan mempromosikan Indonesia sebagai tujuan investasi kepada PMN, pemerintah Indonesia juga perlu menjaga stabilitas ekonomi dan politik Indonesia. PMN sangat berhati-hati dalam menentukan negara tujuan investasi demi menjamin keberlangsungan usaha dan keuntungan mereka. Negara yang mengalami ketidakstabilan secara ekonomi maupun politik adalah hal yang berbahaya 
bagi PMN. Seperti yang terjadi di Venezuela yang dilanda krisis ekonomi dan ketidakstabilan politik sejak Presiden Nicolas Maduro berkuasa menggantikan Hugo Chavez pada Tahun 2013. Kekacauan yang terjadi di Venezuela diawali dengan konflik politik kekuasaan yang kemudian merambat ke krisis ekonomi.

Kondisi ekonomi dan politik Venzuela yang tidak stabil mengakibatkan PMN yang beroperasi di negara tersebut terkena dampaknya. Seperti dilansir dalam situs Kompas.com Setiawan, Sakina, R, (2017) krisis Venezuela mendorong PMN untuk mengurangi kegiatan produksi hingga menghentikan operasinya di sana. Pepsi dan Mondelez mengalami kerugian dari periode 2015 hingga 2016. Sedangkan sejak 2013 hingga 2016, delapan PMN yakni General Mills, Bridgestone Amerika, EFCO, Clorox, Alitalia, Air Canada, Gruma dan Wonder telah memutuskan untuk menghentikan operasionalnya dan pergi dari Venezuela (Muhaimin, 2016). PMN raksasa lain seperti Coca-Cola juga harus mengubah pola produksinya (BBC, 2016). Bahkan General Motors (GM) juga harus menyerah dengan menutup operasionalnya pada tahun 2017 akibat merugi selama krisis Venezuela (Setiawan, Sakina, R, 2017).

Kasus Venezuela memberikan gambaran pada kita apa yang akan terjadi pada PMN jika negara yang mereka tanamkan investasi mengalami konflik politik dan krisis ekonomi. Ketidakstabilan negara tuan tumah menjadikan bisnis PMN menjadi terancam berhenti dan menderita kerugian besar. Faktor kesulitan memperoleh bahan baku yang dialami PMN di Venezuela dapat mengarahkan pada berhentinya operasional PMN. PMN di Indonesia pun mengkhawatirkan hal yang sama apabila bahan baku tidak terpenuhi atau sulit diakses akan mengganggu proses produksi

Itulah mengapa PMN sangat berhati-hati dalam mempertimbangkan calon negara yang akan ditamankan investasi, selain melihat prospek keuntungan juga melihat apakah ada kondisi yang akan mengancam keberlangsungan PMN di negara tersebut. Hal ini menjadi penjelasan logis mengapa Jokowi mengupayakan kondisi politik dan ekonomi Indonesia terlihat stabil dan bahkan berkembang di mata PMN. Jika PMN meninggalkan suatu negara yang sedang tidak stabil, maka akan memperburuk kondisi negara tersebut. Dampak perginya PMN diantaranya terjadi pengangguran dalam jumlah besar secara tiba-tiba yang akan memperparah kondisi ekonomi negara yang sedang dilanda krisis. Berhentinya operasional PMN dapat mengakibatkan pada kelangkaan barang yang sebelumnya diproduksi oleh PMN. Kondisi perginya PMN harus langsung direspon secara cepat oleh pemerintah dengan mengambil alih operasional yang ditinggalkan PMN untuk dijalankan oleh kekuatan dalam negeri untuk mengisi kekosongan PMN. 


\section{Membangun Interdependensi: Upaya Menaikan Daya Tawar}

Lantas, bagaimanakah penggunaan stabilitas ekonomi dan politik sebagai upaya meningkatkan daya tawar pemerintah Indonesia di mata PMN di era Jokowi. Langkah yang ditunjukkan pemerintahan Jokowi sendiri menjadi tanda bahwa perspektif yang digunakan dalam merespon kehadiran PMN merujuk pada perspektif neo-liberal yang memandang optimis terhadap PMN. Secara keseluruhan, alasan pemerintah Indonesia di era Jokowi memandang optimis terhadap PMN mengarah pada keinginan untuk memanfaatkan modal besar yang dimiliki PMN dalam mengembangkan berbagai sektor. Investasi asing yang dibawa oleh PMN memang merupakan salah satu sumber dana yang dapat dihimpun negara selain dari sektor pajak ataupun hutang luar negeri. Selain karena faktor sumber dana, investasi PMN bagi pemerintah Indonesia dipandang sebagai pondasi awal bagi kegiatan ekonomi. Dengan demikian, langkah yang ditempuh pemerintahan Jokowi berkaitan dengan Perspektif neo-liberal yang memandang bahwa kekuatan modal dan teknologi PMN dapat digunakan untuk memaksimalkan potensi ekonomi negara berkembang. Meskipun berpandangan neo-liberal, terdapat upaya keluar dari ketergantungan dengan meningkatkan posisi tawar negara terhadap PMN.

Negara berkembang memiliki peluang untuk menegosiasikan posisi nya terhadap PMN agar negara tidak menjadi ketergantungan. Upaya yang artikel ini anggap sebagai bagian dari peningkatan daya tawar adalah upaya menjaga stabilitas ekonomi dan politik. Hal tersebut didasari pada risiko besar yang akan dihadapi PMN jika negara sasaran investasinya mengalami krisis ekonomi dan politik. Kasus krisis Venezuela adalah salah satu contohnya. Risiko kerugian besar hingga terancam menutup operasionalnya sangat dihindari oleh PMN. Ini yang menjadi penjelasan mengapa pemerintahan Jokowi menjadikan stabilitas ekonomi dan politik Indonesia sebagai daya tawar Indonesia karena PMN bergantung pada stabilitas ekonomi dan politik negara inangnya.

Dalam kasus Indonesia, keluhan PMN kepada Kementerian Perindustrian terkait ketersediaan bahan baku dan hambatan regulasi dapat dilihat sebagai bentuk ketergantungan PMN terhadap negara selaku regulator. Upaya untuk mendengar keluhan PMN oleh pemerintah dapat kita lihat sebagai langkah awal pemerintah dalam upaya mewujudkan stabilitas ekonomi. Selain itu, ekonomi Indonesia yang relatif stabil di tengah situasi ekonomi global yang memanas juga dapat dilihat sebagai perwujudan stabilitas ekonomi.

Di sisi lain, stabilitas ekonomi dan politik negara tidak hanya menguntungkan investasi modal asing. Investasi modal dalam negeri juga dapat berkembang sehingga ke depannya modal dalam negeri akan menjadi pesaing yang seimbang dengan modal PMN. Keseimbangan persaingan modal asing dan dalam negeri tersebut pada akhirnya akan membuat negara tidak lagi bergantung pada modal asing, karena negara memiliki lebih dari satu sumber modal. 
Jika situasi politik pemerintahan Indonesia tidak stabil atau memiliki gejolak penolakan terhadap investasi asing, seperti yang terjadi di Indonesia pada era Orde Lama, maka dapat menurunkan daya tawar pemerintah karena dianggap tidak mampu memberi jaminan atau potensi ekonomi bagi PMN. Secara bersamaan hubungan antara negara dengan PMN dapat saling membutuhkan satu sama lain. Negara membutuhkan aktivitas ekonomi PMN, sebaliknya PMN membutuhkan negara untuk menjamin stabilitas ekonomi politik dan sebagai regulator di negara tersebut.

\section{Pekerjaan Rumah Negara dalam Mengontrol PMN}

Lantas, apakah PMN tidak memiliki sisi negatif? Sebagai entitas ekonomi, PMN tentu memiliki orientasi untuk mencari keuntungan. Berbagai kasus di tingkat nasional maupun internasional menunjukkan bahwa PMN tetaplah sebuah entitas yang memiliki kecenderungan untuk merugikan negara dengan melampaui hukum formal yang berlaku.

Kecurangan PMN yang cukup menggemparkan yakni dalam kasus Paradise Papers. PMN justru berlomba-lomba untuk menghindari pajak negara-negara yang telah mereka tanamkan investasi. Upaya tersebut akan merugikan negara yang bersangkutan karena pemasukan dari sektor pajak mereka akan berkurang, sedangkan PMN tetap dapat menghimpun keuntungan mereka.

Australia melalui Kantor Pajak Australia (ATO) pada 2017 lalu berupaya mengejar perusahaan-perusahaan multinasional yang beroperasi di Australia terkait kewajiban pajak perusahaan tersebut. Tercatat sebanyak 19 perusahaan multinasional diperiksa oleh ATO dalam dugaan menghidari kewajiban pajak. Kasus ini merupakan tindak lanjut dari terbongkarnya dokumen Paradise Papers yang berisi rahasia perusahaan multinasional memanfaatkan tax havens bermuda dan skema permbayaran yang rumit bagi anak perusahaan sehingga dapat mengurangi kewajiban pajak mereka di Australia (Washington, S \& Wilkinson, 2017). Skema PMN mengurangi kewajiban pajak melalui sistem akuntansi yang rumit dikatakan oleh Born \& Leigh (2007) sebagai salah satu alasan mengapa perspektif Global Reach mengkritik keberadaan PMN di negara berkembang sehingga perspektif Global Reach merekomendasikan agar negara berkembang memiliki kontrol terhadap kegiatan PMN dan memperkuat regulasi yang berkaitan dengan PMN.

Ketika Australia pun khawatir dengan skema manipulasi pajak oleh PMN, maka menjadi wajar bila negara berkembang seperti Indonesia juga turut khawatir terkait masalah tersebut. Sektor investasi asing oleh PMN yang diwacanakan sebagai pondasi perekonomian Indonesia justru dapat menjadi permasalahan bagi tersendatnya pendapatan negara dari sektor pajak. Kepentingan pemerintah Indonesia untuk meningkatkan pendapatan negara melalui sektor pajak yang bersumber dari pendapatan PMN menjadi terancam. 
Pemerintah Indonesia di era Jokowi melalui Sri Mulyani sebagai Menteri Keuangan sudah menegaskan bahwa perusahaan multinasional juga wajib membayar pajak karena sudah mendapatkan keuntungan dari kegiatan ekonomi mereka di Indonesia. Salah satu PMN yang telah berhasil didorong untuk melunasi tunggakan pajaknya sesuai dengan regulasi yang berlaku adalah Google Asia Pacific Pte Ltd pada Tahun 2015 (Kusuma, 2017).

Kasus mekanisme yang dilakukan PMN dalam menghindari pajak tidak hanya merugikan secara material, melainkan juga merugikan hubungan antara negara dengan PMN dimana posisi negara dianggap menjadi lebih lemah dari PMN dengan tindakan melangkahi regulasi pajak yang berlaku. Hal tersebut dapat menunjukkan ketidakmampuan negara dalam mengontrol entitas PMN. Langkah yang perlu diterapkan dalam kondisi ini adalah mengembalikan citra kontrol negara dengan menunjukkan ketegasan pemerintah terhadap kepatuhan pembayaran pajak PMN. Selain itu, pemerintah harus selalu mengamati perkembangan PMN agar dapat peka terhadap strategi negatif PMN yang dapat mengurangi pendapatan sektor pajak.

Perspektif neo-liberal yang digunakan pemerintah Indonesia tidak serta merta membiarkan tingkah laku PMN tanpa kontrol. Selain meningkatkan posisi tawar Indonesia, pemerintah juga mengupayakan kontrol terhadap PMN. Kasus Freeport menjadi salah satu contoh ketika entitas negara mencoba menunjukkan kontrolnya kepada PMN. Jokowi menegaskan akan bertindak jika PT Freeport Indonesia sulit untuk berunding dalam polemik Izin Usaha Pertambangan Khusus (IUPK) sebagai pengganti Kontrak Karya (KK) bagi perusahaan yang ingin mengeskpor mineral. Selain dari pihak Presiden Indonesia yang berupaya bertindak tegas pada PT Freeport Indonesia, Menteri Koordinator bidang Kemaritiman Luhut Binsar Pandjaitan juga turut menegaskan bahwa PT Freeport Indonesia seharusnya menghormati undang-undang yang berlaku di Indonesia (Stefanie, 2017). Respon tegas yang diwacanakan oleh Jokowi dan Menterinya tersebut memberikan kesan kepada dunia global bahwa PMN sebagai entitas ekonomi yang beraktivitas di Indonesia tetap harus tunduk pada entitas negara.

\section{Penutup}

Dari berbagai fakta yang telah dikemukakan, artikel ini telah menunjukkan bahwa ketergantungan negara berkembang terhadap investasi PMN bukanlah sebuah keniscayaan. Pemerintah negara berkembang masih memiliki peluang untuk mengarahkan dependensi menjadi interdependensi. Dependensi negara berkembang tidak akan terjadi jika PMN tidak merasakan kondisi ekonomi dan politik yang stabil sehingga menarik untuk berinvestasi. Pemerintah negara berkembang memiliki kekuatan dalam bentuk stabilitas ekonomi dan politik untuk meningkatkan daya tawarnya terhadap PMN. Pandangan Neo-Marx dengan teori ketergantungannya akan relevan jika 
pemerintahan negara berkembang tidak memiliki kemampuan dan langkah yang tepat untuk meningkatkan daya tawarnya di mata PMN.

\section{Daftar Pustaka}

Anoraga, P. (1995). Perusahaan Multinasional dan Penanaman Modal Asing. Pustaka Jaya.

Babic, M., Fichtner, J., \& Heemskerk, E. M. (2017). States Versus Corporations: Rethinking The Power of Business in International Politics. The International Spectator, 52(4), 20-43.

Badan Koordinasi Penanaman Modal (BKPM) RI. (2018). Realisasi Penanaman Modal PMDM-PMA TriwulanIV dan Januari-Desember Tahun 2017. Retrieved from https://www.bkpm.go.id/images/uploads/file_siaran_pers/ Paparan_Indonesia_TW_IV_-_2017_Kepala.pdf

Baihaki, L. (2013). Ekonomi-Politik Kebijakan Impor Garam Indonesia Periode 2007-2012. Jurnal Ilmu Sosial Dan Ilmu Politik, 17(1), 1-16.

BBC. (2016). Kekurangan Pasokan Gula, Coca-cola hentikan produksi di Venezuela, BBC. Retrieved from http://www.bbc.com/indonesia/majalah/ 2016/05/160524_majalah_cocacola_venezuela

Born, H., \& Leigh, I. (2007). Mendorong Akuntabilitas Intelijen: Dasar Hukum dan Praktik Terbaik dari Pengawasan Intelijen (Terj.Ria Nuri Dharmawan). (B. S. Hadiwinata, Ed.). Jakarta: DGAF-FES SSR Vol.I.

Budi, N. (2011). Indonesia Diprediksi Jadi Raja Ekonomi Di Asia Tenggara. Retrieved from http://www.tribunnews.com/bisnis/2011/10/31/indonesiadiprediksi-jadi-raja-ekonomi-di-asia-tenggara

Cochrane, J. (2013). Multinationals Hasten to Invest in Indonesia. Retrieved from http://www.nytimes.com/2013/04/24/business/global/indonesia-seesforeign-investment-surge.html?mcubz=3

Kusuma, H. (2017). Sri Mulyani: Perusahaan yang Penghasilannya dari RI Harus Bayar Pajak.

Leonard, H. J. (1979). Multinational corporations and politics in developing countries. World Pol., 32, 454.

Madeley, J. (2009). Big Business, Poor Peoples: How Transnational Corporations Damage The World's Poor. Zed Books Ltd.

Martini, R. (2015). Persepsi Mahasiswa Fisip Undip terhadap Profil Kabinet Kerja Jokowi. Jumal Ilmiah Ilmu Pemerintahan, 1(2), 34-44. Retrieved from https://ejournal2.undip.ac.id/index.php/jiip/article/view/1618

May, C. (2017). Multinational Corporations in World Development: 40 Years On. Third World Quarterly, 38(10), 2223-2241.

Mohan, G., Asante, K. P., \& Abdulai, A.-G. (2018). Party Politics and The Political Economy of Ghana's Oil. New Political Economy, 23(3), 274-289.

Nizamuddin, A. M. (2008). Declining Risk, Market Liberalization and StateMultinational Bargaining: Japanese Automobile Investments in India, Indonesia and Malaysia. Pacific Affairs, 81(3), 339-359.

Prayogo, C. (2017). Bank Dunia:Perusahaan Multinasional Butuh Regulasi 
Ramah Bisnis. Retrieved from https://www.wartaekonomi.co.id/ read159491/bank-dunia-perusahaan-multinasional-butuh-regulasi-ramahbisnis.html

Putri, Budiati, U. (2018). Chevron Ingin Kepastian Kebijakan Fiskal Pemerintah. Retrieved from https://bisnis.tempo.co/read/1085235/chevron-inginkepastian-kebijakan-fiskal-pemerintah

Rina, D. (2016). Di San Fransisco, Jokowi Sebut Indonesia Tiru Ronald Reagan. Retrieved from https://m.tempo.co/read/news/2016/02/18/090745992/ di-san-fransisco-jokowi-sebut-indonesia-tiru-ronald-reagan

Setiawan, Sakina, R, D. (2017). orporasi Multinasional Ramai-ramai Hengkang dari Venezuela. Retrieved from https://ekonomi. kompas.com/read/2017/04/22/140000926/korporasi.multinasional.ramairamai.hengkang.dari.venezuela

Sklar, R. L. (1976). Postimperialism: A Class Analysis of Multinational Corporate Expansion. Comparative Politics, 9(1), 75-92.

Stefanie, C. (2017). Jokowi Ambil Sikap Tegas jika Freeport Tolak Berunding. Retrieved from https://www.cnnindonesia.com/ekonomi/20170223104251 -85-195566/jokowi-ambil-sikap-tegas-jika-freeport-tolak-berunding/

Tempo.co. (2017). Jokowi Bangga Survei Layak Investasi Tingkatkan Kepercayaan Dunia. Retrieved from https://bisnis.tempo.co/read/ 882763/jokowi-bangga-survei-layak-investasi-tingkatkan-kepercayaan-dunia

Udofia, O. E. (1984). Imperialism in Africa: A Case of Multinational Corporations. Journal of Black Studies, 14(3), 353-368.

Umar, A. R. M. (2012). Ekonomi Politik Perminyakan Indonesia: Analisis Kebijakan Liberalisasi Sektor Hulu Migas Indonesia Pasca-1998. Furnal Ilmu Sosial Dan Ilmu Politik, 16(1), 45-61.

Washington, S, A., \& Wilkinson, M. (2017). ustralia Kejar 19 Perusahaan Multinasional Terkait Pajak. Retrieved from https://news.detik.com/ australia-plus-abc/d-3715367/australia-kejar-19-perusahaan-multinasionalterkait-pajak?n992204australia

White, N. J. (2017). The Settlement of Decolonization and Post-Colonial Economic Development: Indonesia, Malaysia, and Singapore Compared. Bijdragen Tot de Taal-, Land-En Volkenkunde/Fournal of the Humanities and Social Sciences of Southeast Asia, 173(2-3), 208-241.

Widodo, J. (2014). Opening Indonesia: A Conversation With Joko Widodo. Foreign Affairs, 93(6), 56-61. 